\title{
Ulkomaiset eläinten hyvinvointimerkit tarkastelussa
}

\author{
Katriina Heinola ${ }^{1)}$, Tiina Kauppinen ${ }^{2)}$, Jarkko K. Niemi ${ }^{1)}$, Essi Wallenius ${ }^{3)}$, Satu Raussi ${ }^{2)}$ \\ 1)Luonnonvarakeskus, Latokartanonkaari 9,00790 Helsinki, katriina.heinola@luke.fi, \\ jarkko.niemi@luke.fi \\ 2) Eläinten hyvinvointikeskus, Luonnonvarakeskus, Latokartanonkaari 9, 00790 Helsinki, \\ tiina.kauppinen@luke.fi,satu.raussi@luke.fi \\ 3)Armenta Benessi, essi.wallenius@armentabenessi.fi
}

\section{Tiivistelmä}

Useissa maissa on jo vapaaehtoisia eläinten hyvinvointimerkintäjärjestelmiä eläinperäisille tuotteille. Kuluttajien mielenkiinnon kasvaessa järjestelmät ovat saaneet huomattavaakin jalansijaa markkinoilla. Osa järjestelmistä on portaittaisia, mikä auttaa tuottajia pääsemään järjestelmään mukaan pienilläkin hyvinvointiparannuksilla ja kehittämään toimintaansa. Eläinten hyvinvointimerkintä suomalaisen elintarviketuotannon vahvuudeksi -hankkeessa selvitimme markkinoilla olevia vapaaehtoisia hyvinvointimerkkijärjestelmiä sekä niiden vaatimuksia Euroopassa ja Pohjois-Amerikassa. Vanhimmat hyvinvointimerkit ovat olleet käytössä jo kymmeniä vuosia, ja uusia tulee koko ajan. Merkintäjärjestelmät toimivat kuluttajakysynnän ehdoilla. Esimerkiksi Beter Leven -merkillä on jo kattavasti jalansijaa Hollannin sianlihamarkkinoilla. Yksittäisten järjestelmien piirissä on tuhansia tuotantotiloja ja satoja miljoonia eläimiä. Järjestelmässä voi olla useampia vaatimustasoja. Tasot auttavat vastaamaan erilaisten kuluttajaryhmien toiveisiin ja mahdollistavat tuottajille asteittaisen eläinten hyvinvoinnin kehittämisen. Alimpia tasoja on tosin arvosteltu siitä, että ne edistävät eläinten hyvinvointia lakisääteiseen tasoon verrattuna vain vähän. Merkintäjärjestelmät huomioivat erilaisia eläinten hyvinvointiin vaikuttajia tekijöitä, joten niiden vertailu keskenään on haastavaa. Järjestelmät on pääsääntöisesti kehitetty eläinten hyvinvoinnin parantamiseksi, mutta esimerkiksi Red Tractor ja Beef and Lamb Assurance keskittyvät kokonaisvaltaisesti kestävään tuotantoon ottaen huomioon myös ympäristökestävyyden ja eläinten hyvinvoinnin. Ulkomaisissa järjestelmissä on vaatimuksia, joista osa toteutuu jo suomalaisilla tiloilla laajamittaisesti, sekä vaatimuksia, joita Suomessa toteutetaan vain harvakseltaan. Järjestelmissä mukana olevia toimijoita auditoidaan yleensä vuosittain. Tiloja voidaan tarkastaa myös ennalta ilmoittamatta, tai tilat voivat tehdä omavalvontaa. Ulkopuolisen tekemä tarkastus takaa toiminnan luotettavuuden. Järjestelmien rahoitus vaihtelee huomattavasti. Usein se perustuu liiketoiminnan volyymin määrittämiin jäsen- ja lisenssimaksuihin. Tuottajat maksavat usein vain vuositarkastuksista, ja muut kulut jaetaan tuotantoketjun muille toimijoille. Järjestelmät voivat toimia myös lahjoitusvaroin, kauppaketjujen rahoittamina tai rahastomuotoisina. Merkin ylläpitäminen ja laatuvaatimusten täyttäminen aiheuttavat kustannuksia. Hyvinvointimerkitystä tuotteesta on saatava kustannukset kattava lisähinta, jonka kuluttajat ovat valmiit maksamaan. Merkinnän tulee siis yhtäältä edistää eläinten hyvinvointia ja toisaalta huomioida kuluttajien toiveet eläinten hyvinvoinnille. Merkki itse tuotteessa on tärkeä, sillä se kertoo kuluttajalle, miten tuote on tuotettu. Merkinnän on viestittävä selkeästi, miten tuote eroaa tavanomaisesta.

Asiasanat: eläinten hyvinvointi, hyvinvointimerkintäjärjestelmä

\section{Johdanto}

Huoli eläinten hyvinvoinnista on johtanut vapaaehtoisten eläinten hyvinvointia kuvaavien laatujärjestelmien kehittämiseen useissa maissa Euroopassa ja Pohjois-Amerikassa. Järjestelmät edistävät eläinten hyvinvointia sekä näkyvät kuluttajille pakkausmerkintänä. Järjestelmän määrittämien eläinten hyvinvointivaatimusten tulisi ovat korkeammat, kuin maan lainsäädännön vähimmäisvaatimukset, jolloin järjestelmällä voidaan yhtäältä edistää eläinten hyvinvointia tavanomaista tuotantoa enemmän ja toisaalta tuottaa lisäarvoa markkinoille. Järjestelmien haasteita ovat hyvinvointivaatimusten todellinen arvo eläinten hyvinvoinnille ja kuluttajille, järjestelmän markkinointi ja sen saattaminen kuluttajien tietoisuuteen. 
Suomen markkinoilla ei ole yhdenmukaista, kaikki lajit huomioivaa eläinten hyvinvointijärjestelmää, mutta joitakin eläinten hyvinvoinnista kertovia järjestelmiä ja pakkausmerkintöjä on kehitetty ja tuotu markkinoille. Luomutuotannon ehdoissa on lainsäädännön ylittäviä kriteerejä, jotka edistävät eläinten hyvinvointia. Eläinten terveys ETT ry:n ylläpitämät Naseva ja Sikava ovat suomalaiset nauta- ja sikatilat laajasti kattavia terveysluokitusjärjestelmiä. Laatuvastuu on sika-alan kansallinen laatujärjestelmä, joka perustuu eläinterveydenhuoltoon. Kansainvälistä Welfare Quality eläinten hyvinvoinnin mittausmenetelmää, joka huomioi myös eläinten käyttäytymistä, käytetään Juustoportin Vapaan lehmän -tuotesarjassa ja Lidlin Ilona-maidossa. Myös eläinten hyvinvointikorvaus on keino edistää eläinten hyvinvointia, kun tuottajat sitoutuvat tiettyihin toimenpiteisiin ja saavat niistä korvausta.

Tämän tutkimuksen tavoitteena oli kartoittaa markkinoilla olevia ulkomaisia tuotantoeläinten hyvinvointia kuvaavia laatujärjestelmiä ja niiden vaatimuksia. Selvitys on osa Eläinten hyvinvointimerkintä suomalaisen eläintuotannon kilpailukyvyn ja laadun edistäjänä-hanketta. Lisäksi vertasimme lisäksi kunkin merkintäjärjestelmän eläinlajikohtaisia vaatimuksia suomalaisen lainsäädännön asettamiin vaatimuksiin.

\section{Materiaali ja menetelmät}

Selvitimme yhteensä 17 eläinten hyvinvointimerkintäjärjestelmää vaatimuksineen Euroopasta ja Pohjois-Amerikasta (Taulukko 1). Tiedot kerättiin järjestelmien avoimilta internet sivustoilta vuonna 2017. Järjestelmistä saatavilla olevan tiedon määrä ja tarkkuus vaihtelee, mutta yleisesti ottaen tietoa löytyy hyvin siitä, mitä eläinlajeja ja eläintuotteita merkintäjärjestelmien piiriin kuuluu, mikä taho ylläpitää järjestelmää, kuinka usein järjestelmään kuuluvalle eläintuotantotilalle tehdään tarkastuskäynti ja mikä taho tarkastuksista vastaa.

Euroopan markkinoilta tarkastelimme 14 järjestelmää; Tanskan Bedre Dyrevelferdia (2018), Coopin Dyrevelferdia (2018) ja Frilandia (2018), Hollanin Beter Levenia (2018), Saksan Für Mehr Tierschutz (2013), Neuland (2018), Mehr Tierwohl (2018) ja Initiative Tierwohl-järjestelmiä (2018), Sveitsin Coopin Naturaplania ja Naturafarmia (Coop Switzerland 2016), Ranskan Label Rougea (2018), IsoBritannian RSPCA (2018)- ja Red Tractor-järjestelmiä (2018) sekä Irlannin Beef and Lamb Assurance (SBLAS)-järjestelmää (SBLAS 2018). Lisäksi Pohjois-Amerikan markkinoilta vertailuun valittiin Animal welfare approved- (AWA, 2017), Certified Humane- (HFAC, 2017)) ja Global Animal Partnership-järjestelmät (GAP, 2018). Taulukossa 1 on esitetty järjestelmän julkistamisvuosi, järjestelmän ylläpitäjä tai yhteistyötaho, järjestelmän tasojen määrä ja sen kattamat eläinlajit vuonna 2017. Tarkastelussa oli mukana sianlihantuotanto, maidon- ja naudanlihantuotanto, kananmunan- ja broilerinlihantuotanto sekä lampaanlihantuotanto. Yleisimmin merkintäjärjestelmät kattoivat sianlihan-, broilerin-, kananmunan- ja/tai naudanlihantuotannon. Muilla eläinlajeilla taulukossa 1 viitataan esimerkiksi biisoninlihantuotantoon, lohenkasvatukseen tai kasvituotantoon.

Osa järjestelmistä edisti kestävyysnäkökulmia muillakin osa-alueilla kuin eläinten hyvinvoinnin saralla. Tällainen järjestelmä oli esimerkiksi SBLAS. Neuland ja Label Rouge järjestelmiä markkinoidaan ympäristökestävinä ja Naturaplan ja Friland ovat myös luomutuotantoa. 
Taulukko 1. Selvitetyt ulkomaiset eläinten hyvinvointimerkintäjärjestelmät

\begin{tabular}{|c|c|c|c|c|}
\hline $\begin{array}{c}\text { Järjestelmä } \\
\text { (julkistamisvuosi) }\end{array}$ & Valtio & Eläinlajit & $\begin{array}{c}\text { Tas } \\
\text { ot }\end{array}$ & $\begin{array}{c}\text { Järjestelmän ylläpitäjä } \\
\text { (yhteistyössä) }\end{array}$ \\
\hline $\begin{array}{l}\text { Bedre } \\
(2016)\end{array}$ & DK & $\begin{array}{l}\text { Sika, kana (liha ja muna), } \\
\text { kalkkuna }\end{array}$ & 3 & Tanskan ruokaministeriö \\
\hline Beter Leven (2007) & NL & $\begin{array}{l}\text { Sika, kana (liha ja muna), } \\
\text { kalkkuna, nauta } \\
\text { vasikanliha), muut }\end{array}$ & 3 & Eläinten suojalujärjestö (SPA) \\
\hline Coop Dyrevelferd & DK & Sika, kana (liha ja muna) & 4 & $\begin{array}{l}\text { Coop Denmark (Kansallinen } \\
\text { luomuyhdistys, eläinten } \\
\text { hyvinvointiyhdistys) }\end{array}$ \\
\hline $\begin{array}{l}\text { Für Mehr Tierschutz } \\
(2009)\end{array}$ & $\mathrm{DE}$ & $\begin{array}{l}\text { Sika, kana (liha ja muna), nauta } \\
\text { (maito) }\end{array}$ & 2 & Deutscher Tierschutzbund \\
\hline $\begin{array}{l}\text { Coop Switzerland } \\
\text { Naturaplan }\end{array}$ & $\mathrm{CH}$ & $\begin{array}{l}\text { Sika, kana (liha ja muna), nauta } \\
\text { (maito, liha, vasikanliha), } \\
\text { lammas, muut }\end{array}$ & 1 & Coop Switzerland, BioSuisse \\
\hline $\begin{array}{l}\text { Coop Switzerland } \\
\text { Naturafarm (1993) }\end{array}$ & $\mathrm{CH}$ & $\begin{array}{l}\text { Sika, kana (liha ja muna), nauta } \\
\text { (liha, vasikanliha), muut }\end{array}$ & 1 & Coop Switzerland \\
\hline $\begin{array}{l}\text { Label Rouge (1960- } \\
\text { luvulla) }\end{array}$ & FR & $\begin{array}{l}\text { Kana (liha ja muna), kalkkuna, } \\
\text { muut }\end{array}$ & 1 & Label Rouge \\
\hline $\begin{array}{l}\text { RSPCA } \quad \text { assured } \\
(2015)\end{array}$ & UK & $\begin{array}{l}\text { Sika, kana (liha ja muna), } \\
\text { kalkkuna, nauta (liha, maito, } \\
\text { vasikanliha), lammas, muut }\end{array}$ & 1 & $\begin{array}{l}\text { RSPCA Assured, Freedom } \\
\text { Food }\end{array}$ \\
\hline Red Tractor (2000) & UK & Sika, kana (liha ja muna) & 1 & The Assured Food Standards \\
\hline Friland (1992) & DK & Sika, nauta (liha) & 1 & $\begin{array}{l}\text { Friland (Eläinten } \\
\text { hyvinvointiyhdistys) }\end{array}$ \\
\hline $\begin{array}{l}\text { Beef and lamb } \\
\text { assurance (SBLAS) }\end{array}$ & IE & Nauta (liha), lammas & 1 & Board Bia Irish Food Board \\
\hline Neuland (1988) & $\overline{\mathrm{DE}}$ & Sika & 1 & (DTSchB, AbL and BUND) \\
\hline $\begin{array}{l}\text { Animal welfare } \\
\text { approved - AWA }\end{array}$ & USA & Sika, kana (liha ja muna) & 1 & Greener world \\
\hline $\begin{array}{l}\text { Certified Humane } \\
(1998)\end{array}$ & $\begin{array}{l}\text { US, } \\
\mathrm{BR}, \\
\mathrm{CA}\end{array}$ & $\begin{array}{l}\text { Sika, kana (liha ja muna), } \\
\text { kalkkuna, nauta (liha, maito), } \\
\text { lammas, vuohi }\end{array}$ & 1 & Humane Farm Animal Care \\
\hline $\begin{array}{l}\text { Global Animal } \\
\text { Aartnership (2008) }\end{array}$ & US, CA & $\begin{array}{l}\text { Sika, kana (liha ja muna), } \\
\text { kalkkuna, nauta (liha), lammas, } \\
\text { muut }\end{array}$ & $\begin{array}{c}5 \\
(+)\end{array}$ & $\begin{array}{l}\text { Global Animal Partnership } \\
\text { (Whole Foods) }\end{array}$ \\
\hline $\begin{array}{ll}\text { Initiative } & \text { Tierwohl } \\
(2015) & \\
\end{array}$ & $\mathrm{DE}$ & Sika, kana (liha), kalkkuna & & Initiative Tierwohl \\
\hline $\begin{array}{l}\text { Mehr } \quad \text { Tierwohl } \\
(2019-2020)\end{array}$ & $\mathrm{DE}$ & Sika, kana (liha ja muna) & 2 & $\begin{array}{l}\text { Saksan Maatalousministeriö } \\
\text { (BMEL) }\end{array}$ \\
\hline
\end{tabular}

\section{Tulokset}

\section{Järjestelmien valvonta, rahoitusmalli ja ylläpito}

Valtaosassa järjestelmistä kotieläintiloille tehdään valvontatarkastus vähintään kerran vuodessa (Taulukko 2). Bedre Dyvelferd-järjestelmään kuuluville tiloille voidaan tehdä ennalta ilmoittamattomia tarkastuksia (10 \% tiloista). Myös muun muassa Für Mehr Tierschutz-, RSPCA-, SBLAS-, Neuland- ja HFAC-järjestelmissä tehdään ennalta ilmoittamattomia tarkastuksia. Tarkastaja on yleensä riippumaton kolmas osapuoli. Muun muassa HFAC-järjestelmässä on määritetty tarkastajalle koulutusvaatimukset (mm. eläinlääkäri). Osassa järjestelmistä on myös sisäistä valvontaa, jonka järjestelmäorganisaatio tekee itse. 
Taulukko 2. Järjestelmien tarkastustiheys ja tarkastajataho

\begin{tabular}{|c|c|c|}
\hline Järjestelmä & Tarkastustiheys & Tarkastaja \\
\hline Bedre Dyrevelferd & $\begin{array}{l}\text { Tarkastus vuosittain, myös ennalta } \\
\text { ilmoittamattomia tarkastuksia }(10 \%)\end{array}$ & Riippumaton osapuoli \\
\hline Beter Leven & Sertifiointi voimassa yhden vuoden & Riippumaton osapuoli \\
\hline Coop Dyrevelferd & Tarkastus vähintään vuosittain & $\begin{array}{l}\text { Akkreditoitu } \\
\text { sertifiointitaho }\end{array}$ \\
\hline Für mehr tierschutz & $\begin{array}{l}\text { Riskiperusteisia tarkastuksia, ennalta } \\
\text { ilmoittamattomia tarkastuksia sekä sisäisiä } \\
\text { auditointeja }\end{array}$ & Riippumaton sertifioija \\
\hline $\begin{array}{l}\text { Coop Switzerland } \\
\text { Naturaplan }\end{array}$ & Tarkastus vähintään vuosittain & Riippumaton osapuoli \\
\hline $\begin{array}{l}\text { Coop Switzerland } \\
\text { Naturafarm }\end{array}$ & Ei tietoa & $\begin{array}{l}\text { Swiss animal protection } \\
\text { (SAP) }\end{array}$ \\
\hline Label Rouge & $\begin{array}{l}\text { Säännölliset tarkastukset, myös järjestelmän } \\
\text { sisäistä valvontaa }\end{array}$ & $\begin{array}{l}\text { Riippumaton osapuoli, } \\
\text { myös sisäinen valvonta }\end{array}$ \\
\hline RSPCA Assured & Tarkastus vuosittain, myös ennalta ilmoittamatta & $\begin{array}{l}\text { RSPCA Assured } \\
\text { scheme tarkastajat }\end{array}$ \\
\hline Red Tractor & $\begin{array}{l}\text { Osallistuminen järjestelmään uusitaan vuosittain, } \\
\text { naudoille ja lampaille auditointi } 18 \mathrm{kk} \text { välein }\end{array}$ & \\
\hline Friland & $\begin{array}{l}\text { Tarkastus vuosittain, viranomaistarkastus } \\
\text { luomuvalvonnan osalta }\end{array}$ & Danish Plant Directorate \\
\hline SBLAS & $\begin{array}{l}\text { Auditointi } 18 \text { kk välein, myös ennalta } \\
\text { ilmoittamattomia tarkastuksia }\end{array}$ & $\begin{array}{l}\text { Riippumattomat } \\
\text { auditoijat }\end{array}$ \\
\hline Neuland & Tarkastus vuosittain, myös ennalta ilmoittamatta & Ei tietoa \\
\hline AWA & Tarkastus vuosittain & Riippumaton osapuoli \\
\hline HFAC & Tarkastus vuosittain, myös ennalta ilmoittamatta & Akkreditoitu taho \\
\hline GAP & Sertifikaatti voimassa $15 \mathrm{kk}$ & Riippumaton osapuoli \\
\hline Initiative Tierwohl & $\begin{array}{l}\text { Tarkastus vuosittain. Sertifikaatti voimassa } \\
\text { siipikarjalle } 2 \text { vuotta ja sioille } 3 \text { vuotta }\end{array}$ & Riippumaton osapuoli \\
\hline
\end{tabular}

Hyvinvointimerkintäjärjestelmät aiheuttavat kustannuksia toimijoille. Hyvinvointivaatimukset voivat edellyttää kotieläintuottajilta investointeja (mm. suuremmat ulkotarhat tai karsinat), uusia hankintoja (esim. virikkeet tai kuivike) sekä ylimääräistä työpanosta. Myös tuotteiden erillään pitäminen tavanomaisista tuotteista koko ketjussa, jäljittäminen, markkinointi, järjestelmän valvonta ja ylläpito aiheuttavat kustannuksia. Osasta järjestelmiä saatiin tietoa hyvinvointimerkintäjärjestelmän rahoituksesta tai toimijoiden maksamista kustannuksista. Bedre Dyrevelfard on koko tuotantoketjun rahoittama. Beter Leven-, Coop Dyrevelferd-, Für mehr tierschutz-, Red Tractor-, GAP- ja HFACjärjestelmissä toimijat maksavat sertifointi- tai valvontakustannuksen. Initiative Tierwohlin rahoitusmalli poikkeaa muista. Järjestelmä on enemmän elintarviketeollisuuden yhteinen allianssi, jossa kauppa maksaa järjestölle maksua ja joka jaetaan tuottajille, kuin perinteinen laatumerkintä. AWA:1la on lahjoitusperusteinen rahoitusmalli, eikä siitä aiheudu toimijoille esimerkiksi sertifiointikuluja.

Järjestelmien ylläpitäjät tai perustajatahot vaihtelevat. Esimerkiksi Bedre Dyrevelferd on Tanskan valtion hallinnoima, kun taas esimerkiksi Coop-kauppaketjulla on omia hyvinvointijärjestelmiä Tanskassa ja Sveitsissä. Sveitsin luomutuottajien järjestö Bio-Suisse vastaa Naturaplan-merkistä. Saksan valtio tuki merkittävästi rahallisesti hanketta, jonka avulla toteutettiin Für Mehr Tierschutz järjestelmä, joka on Saksan eläinten hyvinvointiyhdistyksen (The German Animal Welfare Association) ylläpitämä merkki. Global Animal Partnership on hyötyä tavoittelematon järjestö, joka koostuu tuottajista, vähittäismyyjistä, eläinten edustajista ja tutkijoista. AWA on yksi Greener Worldin (kestävyyttä edistävä voittoa tavoittelematon järjestö) toteuttama hyvinvointijärjestelmä. Red Tractor on Iso-Britanniassa alkutuotannon ja ruokateollisuuden rahoittama ja omistama merkintäjärjestelmä. 
Neuland perustettiin viiden toimijan yhteistyönä ja sen taustalla on mm. eläinsuojelun, maatalouden edistämisen ja ympäristönsuojelun toimijoita.

\section{Monitasoiset järjestelmät}

Bedre Dyrevelfard, Beter Leven, Coop Dyrevelferd, Für Mehr Tierschutz, Global Animal Partnership sekä Mehr Tierwohl ovat moniportaisia järjestelmiä. Tämä tarkoittaa, että niissä on useampia hyvinvoinnin tasoja, joiden saavuttamiseksi on täytettävä tasosta riippuvat vaatimukset. Tämä mahdollistaa sen, että tuottaja voi päästä järjestelmään mukaan pienemmillä eläinten hyvinvoinnin parannuksilla ja tuottajalla on myös mahdollisuus kehittää toimintaa edelleen eläinten hyvinvoinnin edistämiseksi. Samalla järjestelmä vastaa myös paremmin erilaisten kuluttajaryhmien toiveisiin. Esimerkiksi Tanskalainen Bedre Dyrevelferd-järjestelmä viestii tasoistaan "Parempi - Vielä parempi Paljon parempi"- lausein. Ensimmäisellä tasolla "Parempi" on muun muassa enemmän kuivikkeita sekä tilaa ja sallitaan emakon liikkumisen rajoittaminen porsimisen yhteydessä enintään neljän päivän ajan. "Vielä parempi"- tasolla ei sallita hännän typistystä, vaaditaan ensimmäistä tasoa enemmän kuiviketta ja karsinatilaa ja sallitaan emakon liikkumisen rajoittaminen porsimisen yhteydessä enintään kahden päivän ajan. Korkein taso "Paljon parempi" edellyttää "paljon enemmän" kuiviketta ja tilaa sekä ulospääsyn kaikille sioille. Broilerin osalta merkin ensimmäisellä tasolla vaaditaan hitaammin kasvava rotu, enemmän elintilaa, jalkapohjaterveyden tavanomaista tarkempi seuranta sekä lyhytkestoinen teuraskuljetus. Toisella tasolla tilavaatimus on vielä suurempi ja vaatimuksena on edellisten lisäksi lajityypillinen ruokinta karkearehun muodossa sekä manipuloitavaa materiaalia virikkeeksi. Korkeimmalla tasolla vaaditaan vielä enemmän tilaa sekä ulospääsy kahden ensimmäisen tason vaatimusten täyttämisen lisäksi.

\section{Järjestelmien hyödyt, haasteet ja markkinat}

Järjestelmien tavoite on eläinten hyvinvoinnin edistäminen, mutta lisäksi järjestelmät mainostavat usein myös sitä, että tuottajat saavat suuremman korvauksen tuotteistaan. Kuluttajanäkökulma tuodaan esiin siten, että kuluttajilla on mahdollisuus tukea eläinten hyvinvointia ostamalla hyvinvointimerkittyjä tuotteita. Esimerkiksi Initiative Tierwohl listaa arvoikseen laajan vaikuttavuuden, vapaaehtoisuuden sekä toteutettavuuden. Järjestelmillä on muitakin tavoitteita. Ranskan Label Rouge kertoo hyödyikseen muun muassa korkeamman elintarviketurvallisuuden sekä paremman maun. Tuotteiden jäljitettävyys ja järjestelmän läpinäkyvyys on mainittu monen järjestelmän kohdalla. Esimerkiksi RSPCA:n osalta vaaditaan, että koko ketju on mukana toiminnassa, eli tuote saa merkinnän vasta, kun myös teurastaja, jalostaja ja pakkaaja on sitoutunut järjestelmän vaatimuksiin. RSPCA järjestelmää myös kehitetään jatkuvasti huomioiden muun muassa säädökset sekä tieteellisen tutkimuksen tulokset.

Hyvinvointimerkintäjärjestelmät ovat kohdanneet myös haasteita. Initiative Tierwohl-järjestelmä oli taloudellisissa ongelmissa, jonka vuoksi vaatimukset täyttäviä tuottajia ei voitu ottaa mukaan järjestelmään. Pakkausmerkintöjen yleisenä ongelmana on myös merkin läpinäkyvyys kuluttajille sekä kuluttajien tietoisuus siitä, mitä merkinnät tarkemmin ottaen tekevät. Osa tätä problematiikkaa on se, että merkittävä osa kuluttajista tuntee kotieläintuotannon nykykäytännöt heikosti, jolloin yksittäisiä hyvinvointivaatimuksia voi olla vaikea verrata tavanomaiseen tuotantoon, jos siitäkään ei ole tarkkaa tietoa. Kritiikkiä hyvinvointimerkinnät ovat saaneet myös niiden määrittämien vaatimusten todellisesta hyödystä eläinten hyvinvoinnille. Esimerkiksi People for the Ethical Treatment of Animals -järjestö on kritisoinut GAP-järjestelmää siitä, että sen vaatimukset hädin tuskin ylittävät yleiset käytännöt ja ettei vaatimusten toteutumatta jättäminen ole johtanut toimenpiteisiin riittävän nopeasti (Law360 2015). Tuotantosuunnat myös eroavat toisistaan paljon, jos tilat tarkastetaan esimerkiksi vuosittain ja broilerien kasvatusaika on muutamia viikkoja, niin valtaosaa broilerituotannosta ei tarkisteta ikinä.

Merkintäjärjestelmien toimivuuden edellytys on se, että niillä on markkinoilla riittävä volyymi ja, että hyvinvointimerkittyjä tuotteita ostetaan. Tämä vaatii kuluttajakysyntää eläinten hyvinvoinnille. Vuonna 2015 Initiative Tierwohlissa oli mukana noin 85\% Saksan vähittäismyyjistä (vuoden 2017 tiedon mukaan). Järjestelmä kattoi 12\% sioista ja noin 35\% siipikarjasta Saksassa ja tavoite oli nostaa osuudet sikojen osalta 20\%:iin ja siipikarjan osalta 60\%:iin. Vuonna 2007 perustetun Beter Levenin markkinaosuus kestävistä tuotemerkeistä, joita on maassa kymmenkunta, oli noin kolmannes. Esimerkiksi sianlihan osalta markkinaosuus Hollannin supermarketeissa oli noin 70\% vuonna 2017. 
Bedre Dyrevelferd kehitettiin vuonna 2016 ja seuraavana vuonna tiloja oli mukana runsas 150 . Merkki on Tanskan valtion hallinnoima ja kunnianhimoisena tavoitteena on saada Tanskan markkinoista ajan myötä haltuun jopa $30 \%$. Lähtökohtaisesti järjestelmässä otettiin tavoitteeksi noin 12-15\% markkinaosuus.

\section{Hyvinvointikriteerit merkintäjärjestelmissä}

Yleisiä vaatimuksia merkintäjärjestelmissä eläinlajista riippumatta ovat eläinten paremmat mahdollisuudet toteuttaa käyttäytymistarpeitaan, erityisesti liikkumisen tarvetta. Liikkumisen vapaus ja kytkemättömyys, häkittömyys, lisätila, kuivitusmateriaalit ja ulospääsy, liittyvät kaikki olennaisten käyttäytymistarpeiden toteuttamisen mahdollisuuteen. Kivuliaat toimenpiteet yleensä joko kielletään tai niiden yhteydessä vaaditaan kivunhoitoa. Ruokintaan liittyviä vaatimuksia ovat muun muassa porsaiden vähimmäisvieroitusikä, vasikoiden maitojuottokauden vähimmäispituus sekä nautojen vapaa vedensaanti. Kasvunopeuden rajoittaminen on yleinen vaatimus broilerien osalta.

Tarkasteltaessa vaatimuksia resurssi- ja eläinperäisten kriteerien näkökulmasta, resurssiperäisiä on huomattavasti enemmän. Resurssiperäisillä tarkoitetaan eläinten hyvinvoinnin edellytyksiä, esimerkiksi tilan tai kuivikkeen määrää. Eläinperäiset viittaavat suoraan eläimestä havaittaviin asioihin, esimerkiksi eläimen käytökseen tai sen ihon tai karvapeitteen kuntoon.

\section{Kananmunantuotanto}

Kananmunatuotannon osalta tarkasteltiin Beter Leven-, Für Mehr Tierschutz-, label Rouge-, Naturafarm- (Coop free range), Naturaplan- (Organic Biosuisse), Neuland-, RSPCA-, Certified Humane- sekä GAP-järjestelmiä (lähteet ${ }^{1}$ ). Nokantypistys oli sallittu joissain hyvinvointijärjestelmissä, kuten GAP:in 1- ja 2- tasoilla (hautomossa infrapunasäteilyä käyttäen) sekä Certified Humane- ja RSPCA-järjestelmissä. Merkeissä rajoitettiin usein parvikokoa 500-6000 lintuun. Pesiä vaadittiin yksi 5-6 lintua kohden ja orsivaatimukset lintua kohden vaihtelivat 12,5 ja 20 senttimetrin välillä. Sisällä tilaa vaadittiin $0,1-0,17$ neliömetriä lintua kohden. Ulkona tilaa vaadittiin lintua kohden 0,45 jopa 5,0 neliömetriin. Häkittömyys oli vaatimuksena kaikissa järjestelmissä. Pimeän jakson pituudeksi määriteltiin 6-16 tuntia.

\section{Maidon- ja naudanlihanlihantuotanto}

Maidontuotantoon liittyviä vaatimuksia on Coop Denmark, Für mehr tierschuzt, Naturafarm (Haymilk), Naturaplan, Red Tractor, RSPCA, AWA ja HFAC-järjestelmissä (lähteet ${ }^{2}$ ). Naudanlihantuotantoon

\footnotetext{
${ }^{1}$ Beter Leven https://beterleven.dierenbescherming.nl/fileupload/pdf_sterren_consumenten/Tekst_BLk_leghennen.pdf https://beterleven.dierenbescherming.nl/zakelijk/deelname/criteria Coop Switzerland

https://www.coop.HFAC/content/dam/act/themen/hauptthemen/tierwohl/Coop_Tierwohlrapport2016_e.pdf

Für mehr Tierschutz https://www.tierschutzlabel.info/fileadmin/user_upload/Dokumente/Tierschutzlabel-Broschuere.pdf

Label Rouge http://www.volaillelabelrouge.com/en/what-are-label-rouge-eggs/

Neuland http://www.neuland-fleisch.de/assets/files/Richtlinien/richtlinien-legehennen-stand-nov.-2017.pdf

RSPCA https://science.RSPCA.org.uk/sciencegroup/farmanimals/standards/layinghens
}

\footnotetext{
${ }^{2}$ AWA https://animalwelfareapproved.us/standards/dairy-cattle-2017

Coop Denmark http://dyrevelfcerd.coop.dk/media/1081/kriterer-for-malkekvaeg-og-oksekoed-fra-malkekvaeg.pdf Coop Switzerland

https://www.coop.HFAC/content/dam/act/themen/hauptthemen/tierwohl/Coop_Tierwohlrapport2016_e.pdf

Für mehr Tierschutz https://www.tierschutzlabel.info/fileadmin/user_upload/Dokumente/Tierschutzlabel-Broschuere.pdf

HFAC https://certifiedhumane.org/wp-content/uploads/Std14.DairyCattle.2A-3.pdf

Red Tractor https://assurance.redtractor.org.uk/contentfiles/Farmers-6802.pdf? $=636359680695407277$

RSPCA https://science.RSPCA.org.uk/sciencegroup/farmanimals/standards/dairycattle

AWA https://animalwelfareapproved.us/standards/beef-cattle-2017/

Beter Leven https://beterleven.dierenbescherming.nl/rund-1ster,

https://beterleven.dierenbescherming.nl/zakelijk/deelname/criteria

Für mehr Tierschutz https://www.tierschutzlabel.info/fileadmin/user upload/Dokumente/Tierschutzlabel-Broschuere.pdf GAP https://globalanimalpartnership.org/wp-content/uploads/2017/06/5-Step\%C2\%AE-Animal-Welfare-Rating-Standardsfor-Beef-Cattle-v1.0.pdf

HFAC https://certifiedhumane.org/wp-content/uploads/Std14.BeefCattle.3M-1.pdf
} 
kriteerejä asettavat SBLAS, Beter Leven, Certified Humane, Naturaplan, Naturafarm, Red Tractor, RSPCA, AWA sekä GAP -järjestelmät Naudoilla vaaditaan yleisesti puudutuksen ja/tai kivunlievityksen käyttöä nupoutuksen yhteydessä. Vettä täytyy olla naudoilla jatkuvasti tai riittävästi saatavilla. Vasikoiden osalta juottokauden pituuden vaatimukset vaihtelevat viidestä viikosta jopa 13 viikkoon (Coop Denmark taso 3).

Olkikuivitusta tai vastaavaa vaaditaan kaikissa järjestelmissä, tosin tietoa ei löytynyt Sveitsin Haymilk ja Naturaplan-järjestelmistä tai Red Tractor-järjestelmästä. Ulospääsy ja laidunnus ovat vaatimuksina useissa järjestelmissä tietynmittaisin ajanjaksoin ja jatkuvana Fyhr Mehr Tierschutz premiumjärjestelmässä sekä AWA:järjetestelmässä. Kytkemisen pitämisen kieltävät muut tarkastellut järjestelmät lukuunottamatta Haymilkia, Naturaplania sekä Red Tractoria. Lehmien tilavaatimus vaihtelee järjestelmästä riippuen 6-10 neliöön, vasikoiden 2,5-5 neliöön. Teuraskuljetuksen maksimikesto on korkeintaan kahdeksan tuntia Coop Denmarkin kolmostasolla, Haymilkissa, Naturaplanissa, RSPCA:ssa sekä AWA-järjestelmissä.

Lihanaudoilla emoa ja vasikkaa on pidettävä yhdessä vähintään 3-6 kuukautta järjestelmästä riippuen. Ulospääsy tai laidun on yleinen vaatimus myös lihanaudoilla. Kastraatio on sallittu kaikissa järjestelmissä, Beter Levenissa ja Neulandissa kivunlievityksellä.

\section{Sianlihantuotanto}

Sikojen osalta tarkastelussa olivat Beter Leven, Bedre Dyrevelferd, Coop Denmark, Für Mehr Tierschutz Friland, Initiative Tierhwohl, Mehr Tierwohl, Naturafarm, Naturaplan, Red Tractor, RSPCA, AWA, HFAC ja GAP- järjestelmät (lähteet ${ }^{3}$ ). Sikojen tuotannossa yleisiä vaatimuksia ovat hännäntypistämisen ja hampaiden katkaisun kieltäminen. Jossain järjestelmissä, kuten Beter Leven, Coop Denmark ja Fyhr Mehr Tierschutz karjuporsaiden kastraatio on sallittu kivunlievityksellä. Porsitushäkin käyttö on usein kielletty tai rajoitettu 2-5 päivään. Tilavaatimukset vaihtelevat paljon järjestelmittäin, mutta useat järjestelmät vaativat tiettyä tilaa esimerkiksi lihasioille, välitysporsaille tai tiineille emakoille. Olkikuivitus tai vastaava vaaditaan käytännössä kaikissa järjestelmissä, Red Tractoria lukuunottamatta. Ulospääsy vaaditaan Beter Levenin, Bedre Dyrevelferdin, Coop Denmarkin,

Neuland http://www.neuland-fleisch.de/assets/files/Richtlinien/richtlinien-rinder-stand-nov.-2017.pdf

Red Tractor https://assurance.redtractor.org.uk/contentfiles/Farmers-6800.pdf? $=636343316823538543$

RSPCA https://science.RSPCA.org.uk/sciencegroup/farmanimals/standards/beefcattle

SBLAS

https://www.bordbia.ie/industry/farmers/quality/BeefSchemeStandards/Sustainable_Beef_and_Lamb_Assurance_Scheme_Sta ndard.pdf

${ }^{3}$ AWA https://animalwelfareapproved.us/standards/pig-2017/

Bedre Dyrevelferd

https://www.foedevarestyrelsen.dk/SiteCollectionDocuments/26_Kampagne/Dyrevelf\%C3\%A6rdsm\%C3\%A6rket/Faktaark_ dyrevelf\%C3\%A6rd_UK_160817.pdf

Beter Leven https://̄beterleven.dierenbescherming.nl/fileupload/pdf_sterren_consumenten/Tekst_BLk_varkens.pdf

Coop Switzerland http://www.coop.ch/content/dam/act/themen/hauptthemen/tierwohl/Coop_Tierwohlrapport2016_e.pdf

Friland https://www.friland.com/media/1523/friland-free-range-code-of-practice.pdf

Für Mehr Tierschutz https://www.tierschutzlabel.info/fileadmin/user_upload/Dokumente/Tierschutzlabel-Broschuere.pdf

GAP https://globalanimalpartnership.org/wp-content/uploads/2017/07/5-Step-Animal-Welfare-Rating-Standards-for-Pigs-

v2.2.pdf

HFAC https://certifiedhumane.org/wp-content/uploads/Std18.Pigs_.1A-2.pdf

Initiative Tierwohl https://initiative-tierwohl.de/wp-

content/uploads/2015/01/20170101_rev01_ITW_Handbuch_Kriterienkatalog_Schweinemast.pdf

https://initiative-tierwohl.de/wp-

content/uploads/2015/01/20170101_rev01_ITW_Handbuch_Kriterienkatalog_Sauenhaltung.pdf

Mehr Tierwohl

http://www.bmel.de/SharedDocs/Downloads/Broschueren/Tierwohl.pdf;jsessionid=548F1C4F08A23EA6AAC7BB789A5FD1

6 B. 1 cid385? blob=publicationFile

Red Tractor https://assurance.redtractor.org.uk/contentfiles/Farmers-6801.pdf?_ $=636359680512574955$

RSPCA https://science.RSPCA.org.uk/sciencegroup/farmanimals/standards/pigs 
Für Mehr Tierschutzin, Mehr Tierwohlin ja GAP korkeimmilla tasoilla sekä Sveitsin Coopin ja Yhdysvaltain AWA-järjestelmissä. Yhtäjaksoinen kahdeksan tunnin pimeä aika vaaditaan muutamissa järjestelmissä, kuten Beter Levenissä ja GAP:ssa, RSPCA-järjestelmä vaatii kuuden tunnin yhtäjaksoisen pimeän ajan. Teuraskuljetuksen maksimikesto vaihteli neljästä tunnista (Für Mehr Tierschutz) jopa 16 tuntiin (GAP).

\section{Broilerinlihan tuotanto}

Broilerinlihantuotannon osalta tarkasteltiin Beter Leven-, Coop Denmark-, Für Mehr Tierschutz-, Label Rouge-, Naturaplan-, Naturafarm-, Neuland-, RSPCA-, AWA-, GAP- ja Certified Humane-järjestelmiä $\left(\right.$ lähteet $\left.{ }^{4}\right)$. Broilerituotannossa merkittävä vaatimus oli lintujen kasvun rajoittaminen 35-68 kilogrammaan vuorokaudessa. Eniten kasvua rajoittivat AWA, Neuland, Beter Leven ja Für Mehr Tierschutz sekä GAP tasolla 5. Jatkuva 6-8 tunnin pimeä jakso oli yleinen vaatimus. Ulkoilumahdollisuutta vaativat kaikki järjestelmät Coop Denmarkia ja GAP:in 1-tasoa lukuun ottamatta. Tilavaatimukset vaihtelivat enintään 10-19 neliömetriin lintua kohti tai 21-32 kilogrammaan neliömetriä kohti. Virikevaatimukset olivat yleisiä ja ne edellyttivät esimerkiksi hiekkakylpylaatikoita. Teuraskuljetuksen maksimikestoa oli rajoitettu 2-10 tuntiin.

\section{Lampaanlihantuotanto}

Naturaplan, Lamb scheme Ireland, AWA, HFAC and GAP-järjestelmät olivat mukana tarkastelussa lampaanlihantuotannon osalta (lähteet ${ }^{5}$ ). Hännäntypistys sallitaan edelleen useissa järjestelmissä, GAPjärjestelmissä jopa kahdeksan viikkoiseksi asti. Kastraatio sallitaan kaikissa tarkastelluissa järjestelmissä GAP 5-tasoa lukuun ottamatta, GAP 1- ja 4-tasoissa 6-8 viikon ikään asti. Keritseminen on suoritettava usein vähintään vuosittain. Teurasmatka on rajoitettu kahdeksaan tuntiin useimmissa järjestelmissä, mutta GAP taso 1 sallii 18 tunnin teurasmatkan. Uuhien kuivitetun tilan vaatimukset vaihtelevat 1,2 neliöstä 1,4 neliöön. Vieroitettujen lampaiden kuivitettu tilavaatimus on 0,7 neliöstä 0,9 neliöön. Ritilälattiat ovat usein kielletty. GAP tasot 4 ja 5 vaativat jatkuvan laitumelle pääsyn, samoin AWA. Naturaplan-järjestelmässä vaaditaan laitumelle pääsy 13 päivänä kuukaudessa ja kasvukaudella 26 päivänä kuukaudessa.

\footnotetext{
${ }^{4}$ Beter Leven https://beterleven.dierenbescherming.nl/zakelijk/deelnemers/criteria-en-info/vleeskuikens Coop Denmark http://dyrevelfoerd.coop.dk/til-producenterne/

Coop Switzerland

https://www.coop.HFAC/content/dam/act/themen/hauptthemen/tierwohl/Coop_Tierwohlrapport2016_e.pdf

Fur mehr Tierschutz https://www.tierschutzlabel.info/fileadmin/user_upload/Dokumente/Tierschutzlabel-Broschuere.pdf Label Rouge http://www.volaillelabelrouge.com/en/traditional-animal-husbandry-methods-make-a-great-deal-of-difference/ Neuland: http://www.neuland-fleisch.de/assets/files/Richtlinien/rl-masthuehner-02102015.pdf RSPCA https://science.RSPCA.org.uk/sciencegroup/farmanimals/standards/chickens AWA https://animalwelfareapproved.us/standards/meat-chicken-2018/

HFAC https://certifiedhumane.org/wp-content/uploads/Std14.Chickens.2A-3.pdf

GAP https://globalanimalpartnership.org/wp-content/uploads/2017/08/UPDATEDGAP-Standard-for-Meat-Chickens-v3.0FINAL.pdf

${ }^{5}$ AWA https://animalwelfareapproved.us/standards/sheep-2018/

GAP https://globalanimalpartnership.org/wp-content/uploads/2017/07/5\%E2\%80\%90Step\%C2\%AE-Animal-Welfare-

Rating-Pilot-Standards-for-Meat-Sheep-v1.2.pdf

HFAC https://certifiedhumane.org/wp-content/uploads/Std13.Sheep_.2A-3.pdf

RSPCA https://science.RSPCA.org.uk/sciencegroup/farmanimals/standards/sheep

SBLAS

https://www.bordbia.ie/industry/farmers/quality/BeefSchemeStandards/Sustainable_Beef_and_Lamb_Assurance_Scheme_Sta ndard.pdf
} 


\section{Tulosten tarkastelu}

Vaatimukset eläinten hyvinvoinnin edellytysten osalta vaihtelivat paljon järjestelmästä riippuen. Yleisesti vaatimukset ylittivät EU:n eläinsuojelusäädösten vähimmäisvaatimukset. Moniportaisten järjestelmien korkeimpien tasojen vaatimukset olivat eläinten hyvinvoinnin edellytysten näkökulmasta korkealla tasolla. Korkealle asetetuilla vaatimuksilla on potentiaalia edistää enemmän eläinten hyvinvointia. Portaittaisuus myös mahdollistaa sen, että järjestelmään liittymisen kynnys on matalampi. Moniportaisuus voi auttaa myös tuottajaa kehittämään toimintaansa pidemmällä aikavälillä.

Sørensen ja Schrader (2019) totesivat sikojen hyvinvointimerkintäjärjestelmien vaatimusten olevan paljolti resurssiperäisiä ja vähemmän eläinperäisiä. Eläinperäiset vaatimukset voivat kuluttajanäkökulmasta vaikuttaa negatiivisilta. Esimerkiksi ihovauriot, paiseet tai porsaskuolleisuus, tai ihovaurioiden ja paiseiden vähäinen määrä ja pieni porsaskuolleisuus voivat olla kuluttajamarkkinoinnissa viestinnällisesti haastavia, vaikkakin todellisia eläimen hyvinvoinnin tilasta kertovia mittareita. Eläinperäiset mittarit ovat myös työläämpiä todentaa, sillä esimerkiksi eläinyksilön käyttäytymisen tarkkailu on haastavampaa kuin määrittää eläinyksilön käytettävissä olevan tilan määrä.

Uusilla järjestelmillä, kuten Bedre Dyrevelferd, oli kunnianhimoisia tavoitteita siinä, miten suurta markkinaosuutta merkinnälle tavoitellaan. Sekä kuluttajat että tuottajat on saatava heti alussa kiinnostumaan järjestelmästä ja näkemään sen tuomat hyödyt omasta näkökulmastaan, jotta merkintäjärjestelmästä kehittyy elinvoimainen. Suomessa on kotieläintuottajia, jotka voisivat jo nykyisellä toiminnallaan ja eläinten hyvinvoinnin tasolla päästä mukaan useisiin tarkasteltuihin järjestelmiin. Luomutuottajat ovat esimerkiksi sitoutuneet suurempiin tilavaatimuksiin ja eläinten ulospääsyyn ja Juustoportin Vapaan lehmän maitotilat toteuttavat tiettyjä lakisääteisen vaatimustason ylittäviä eläinten hyvinvointitoimenpiteitä.

\section{Eläinten hyvinvointimerkinnän mahdollisuudet Suomessa hyvinvointivaatimusten näkökulmasta}

Ulkomaisia hyvinvointimerkintäjärjestelmien vaatimuksia tarkasteltiin myös siitä näkökulmasta, miten ne täyttävät eläinten hyvinvointia koskevien säädösten vähimmäisvaatimukset Suomessa. Näin pyrittiin selvittämään, mihin eläinten hyvinvointiin vaikuttaviin tekijöihin voitaisiin kiinnittää huomiota kotimaiseen tuotantoon ja kotimaisille markkinoille suunnatussa eläinten hyvinvointimerkintäjärjestelmässä.

Suomessa säädöksin on esimerkiksi kielletty sikojen häntien ja kanojen nokkien typistys. Edellä mainitut ovat vaatimuksina monissa selvitetyissä vapaaehtoisissa hyvinvointimerkintäjärjestelmissä. Järjestelmää ei kuitenkaan voida rakentaa lainsäädännän vähimmäisvaatimusten varaan, vaan kriteereiden on hyvinvointimerkintäjärjestelmässä ylitettävä vähimmäisvaatimukset. Suomen eläintuotannossa on laajalti käytössä ennaltaehkäisevä terveydenhuolto, missä huomioidaan esimerkiksi vasikoiden nupoutuksen ja karjuporsaiden kastraation kivunhoito, vaikka nämä eivät ole meillä säädösperustaisia vaatimuksia. Eläinten kansallisen terveydenhuollon järjestelmät sopisivat hyvin osaksi suomalaista eläinten hyvinvointia kuvaavaa laatumerkintää.

Eläinten hyvinvointia kohentavia toimenpiteitä voisi Suomessa kohdistaa etenkin eläinten liikkumisen vapauteen eli kytkemättömyyteen, häkittömyyteen sekä eläinten ulospääsyyn, jaloitteluun ja/tai laidunnukseen. Myös emon ja jälkeläisen välisen suhteen, vierihoidon, mahdollistavat kriteerit voisivat sopia suomalaiseen hyvinvointimerkkikonseptiin. Nämä voisivat tuota kilpailuetua ulkomaisiin merkkeihin verrattuna. Eläinten lastaus, kuljetus ja purku teurastamolle ovat eläimen elämän stressaavia vaiheita. Suomen teurastamoverkosto on harva, ja joskus esimerkiksi nautoja voidaan joutua kuljettamaan kauan. Teuraskuljetusten keston rajoittamista voitaisiin myös pohtia suomalaisen hyvinvointimerkintäjärjestelmän yhtenä kriteerinä. 


\section{Johtopäätökset}

Maailmalla on useita eläinten hyvinvointia kuvaavia laatumerkintäjärjestelmiä. Osa järjestelmistä on ollut markkinoilla jo pitkään. Suomalaiset ovat Eurobarometrin mukaan jopa huolestuneempia eläinten hyvinvoinnista kuin eurooppalaiset keskimäärin (TNS opinion \& social 2015), joten kiinnostusta eläinten hyvinvointijärjestelmää kohtaan on. Kiinnostus ei kuitenkaan pelkästään riitä, vaan kuluttajilta vaaditaan myös riittävää maksuhalukkuutta eläinten hyvinvoinnin edistämiseksi ja kustannusten kattamiseksi. Hyvinvointijärjestelmän toteutumisen näkökulmasta tärkeää on sen onnistunut markkinointi ja merkityksen välittäminen kuluttajille. Muissa maissa hyvinvointimerkintäjärjestelmiä toteuttavien tahojen kirjo on laaja, joten Suomessakin aloitteen teko voi olla mahdollista usealle eri toimijalle.

Suomen kuluttajamarkkinoille voi ennen pitkää tulla eläinten hyvinvointimerkittyjä eläintuotteita esimerkiksi muista EU maista. Tanskan Bedre Dyrevelfærd merkintäjärjestelmään hyväksytään myös Tanskan ulkopuolista eläintuotantoa, jos se täyttää järjestelmän vaatimukset. Luomutuotanto ei välttämättä takaa automaattista pääsyä hyvinvointimerkintäjärjestelmään, vaan järjestelmän ehtojen tilatason todentaminen kuuluu olennaisena osana kuluttajalle uskottavaa hyvinvointimerkkiä. EU:n alueella on kiinnostusta myös Unionin yhteiseen eläinten hyvinvointimerkintäjärjestelmään (Euroopan Unionin Neuvosto 2019). Tällaisen EU:n yhteisen järjestelmän kriteereistä sopiminen on kuitenkin aikaa vievää ja eurooppalaiset toimijat ovatkin monella tasolla kehittäneet omia eläinten hyvinvointimerkintäjärjestelmiään. Tuotteiden vertailtavuuden mahdollistamiseksi vaatimuksia ja niiden mittausta olisi perusteltua yhdenmukaistaa.

\section{Kiitokset}

Tutkimus on osa Eläinten hyvinvointimerkintä suomalaisen eläintuotannon kilpailukyvyn ja laadun edistäjänä-hanketta. Hankkeen toteuttavat Luonnonvarakeskus ja Pellervon taloustutkimus ja sitä ovat rahoittaneet maatilatalouden kehittämisrahasto (MAKERA) sekä A-tuottajat, HKScan, Valio, Arla, Juustoportti food, Lidl, Maa- ja metsätaloustuottajain keskusliitto ja SEY Suomen eläinsuojelu.

\section{Kirjallisuus}

AWA 2017. Certified Animal Welfare Approved by AGW. https://agreenerworld.org/certifications/animalwelfare-approved/

Bedre Dyrevelferd 2018. Viitattu 31.8. 2018. https://www.foedevarestyrelsen.dk/kampagner/Bedre-dyrevelfaerd/ Sider/forside.aspx

Beter Leven 2018. Viitattu 31.8.2018. https://beterleven.dierenbescherming.nl/zakelijk

CFAC 2017. Viitattu 31.8.2018. https://certifiedhumane.org/

Coop Switzerland 2016. Animal welfare Report 2016. Coop Switzerland. Coop Genossenschaft http://www.coop.ch/content/dam/act/themen/hauptthemen/tierwohl/Coop_Tierwohlrapport2016_e.pdf Coop Tanska 2018. Viitattu 31.8.2018. http://xn--dyrevelfrd-k6a.coop.dk/dyrevelfaerdshjertet/

Euroopan Unionin Neuvosto 2019. Neuvoston päätelmät eläinten hyvinvoinnista kestävän eläintuotannon erottamattomana osana. 14975/19 https://data.consilium.europa.eu/doc/document/ST-14975-2019-INIT/fi/pdf Friland 2018. https://www.organicdenmark.com/friland-as Für Mehr Tierschutz 2013 Zeichen für ein besseres Leben. Viitattu 31.8.2018 https://www.tierschutzlabel.info/home/

GAP 2018. Viitattu 31.8.2018. https://globalanimalpartnership.org/

Initiative Tierwohl 2018. Viitattu 31.8.2018. https://initiative-tierwohl.de/

Label Rouge 2018. Viitattu 31.8.2018. http://www.volaillelabelrouge.com/

Law360 2015. PETA Calls Whole Foods' Animal Welfare Standards A 'Sham'. Syyskuu 2015. https://www.law360.com/articles/705412

Mehr Tierwohl 2018. Viitattu 31.8.2018.

http://www.bmel.de/SharedDocs/Downloads/Broschueren/Tierwohl.pdf;jsessionid=548F1C4F08A23EA6AAC7 BB789A5FD16B.1_cid385?_blob=publicationFile

Neuland 2018. Viitattu 31.8.2018. http://www.neuland-fleisch.de/

Red Tractor 2018. Viitattu 31.8.2018. https://www.redtractor.org.uk/

RSPCA 2018. Viitattu 31.8.2018. https://www.rspca.org.uk/

SBLAS 2018. Viitattu 31.8.2018. https://www.bordbia.ie/ 
Sørensen, J. T. \& Schrader, L. 2019. Labelling as a Tool for Improving Animal Welfare-The Pig Case. Agriculture 9:123. https://doi.org/10.3390/agriculture9060123

TNS opinion \& social 2015. Special Eurobarometer 442 - November - December 2015 (2016). “Attitudes of Europeans towards Animal Welfare".

https://ec.europa.eu/COMMFrontOffice/publicopinion/index.cfm/Survey/getSurveyDetail/instruments/SPECIAL /surveyKy/2096 